\title{
Conceptual model for improving quality of teacher in Indonesian vocational school
}

\author{
Agung Panji Sasmito, Djoko Kustono, Purnomo, Hakkun Elmunsyah \\ Postgraduate Program, Engineering Faculty, Universitas Negeri Malang, Indonesia
}

\begin{tabular}{|c|c|}
\hline Article Info & ABSTRACT \\
\hline Article history: & Indonesia faces vocational teachers' shortage both in the quantity and \\
\hline Received Nov 16, 2019 & $\begin{array}{l}\text { One of Indonesian goverments' efforts to overcome that problem is } \\
\text { a Dual Expertise Program (DEP) to produce dual expertise teachers }\end{array}$ \\
\hline Revised Jan 11,2020 & for vocational schools. However, the quality of dual expertise vocational \\
\hline Accepted Feb 16, 2020 & $\begin{array}{l}\text { teacher is still questionable. The purpose of this article is to give an idea } \\
\text { related to the conceptual model framework for improving the quality of }\end{array}$ \\
\hline Keywords: & $\begin{array}{l}\text { vocational teachers demonstrated by the teachers' achievements. The authors } \\
\text { of this article discuss factors that have an impact on the quality of vocational }\end{array}$ \\
\hline Dual & teachers and describe a framework based on a literature review that might \\
\hline Teachers achievement & contribute to improving the quality of vocational teachers, especially dual \\
\hline Teachers quality & expertise vocational teachers. Based on the results of the article found that to \\
\hline Vocational teachers & $\begin{array}{l}\text { increasing self-efficacy and transferable skills, in addition to pay attention to } \\
\text { teacher's initial expertise and teaching experience. }\end{array}$ \\
\hline
\end{tabular}

This is an open access article under the CC BY-SA license.

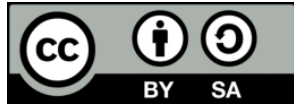

Corresponding Author:

Agung Panji Sasmito,

Postgraduate Program, Engineering Faculty,

Universitas Negeri Malang,

Semarang 5 Street, Malang 65145, Indonesia.

Email: agungpanjisasmito@lecturer.itn.ac.id

\section{INTRODUCTION}

Today, the challenges of vocational schools in Indonesia are gradually higher since the inception of Indonesian National Qualifications Framework that vocational graduates can better suit the needs of industry [1], This is in line with the nature of the Indonesian Vocational School as one of the organizers of vocational education that prepares individuals to enter the workforce in accordance with the employment needs $[2,3]$. The fulfillment of the needs of the labor is fulfilled with the implementation of expertise in vocational school in accordance with the needs of the workforce [4-6].

As time and technology flows in VUCA era, jobs and ways of working evolve too [7, 8]. Labor needs also changed, including the needs of vocational educators, especially vocational teacher [9]. However, at this time in Indonesia, shortages of vocational teacher is occurred [10]. Vocational teacher in some expertise programs exceed the needs, whereas in other expertise programs is less than the number of teachers needed [11]. In addition, the quality of vocational teachers is also one of the problems of education in Indonesia [12].

So far, Indonesian government has implemented Vocational Education Revitalization to improve the quality of vocational education in Indonesia, including improving the quality of vocational teachers and increasing the quantity of vocational teachers through the Dual Expertise Program (DEP) [13, 14]. As far as DEP is implemented, teacher achievement as a reflection of the quality of the dual expertise teacher is still 
questionable [13], and there is no research that addresses the quality of dual expertise teachers. However, investigations regarding efforts to improve the quality of vocational teachers are still needed.

Based on this explanation, it is known that increasing the achievement of dual expertise teachers is one thing that needs to be considered. Therefore, this paper aims to formulate a conceptual model framework to improve the quality of dual expertise teachers including hard skills and soft skills

\section{RESEARCH METHOD}

This study aimed to describe the factors that influence the quality of dual expertise teachers. The quality of the dual expertise teacher in this study is emphasized on the achievements of DEP participant teachers. The literature review was conducted to propose the framework for improving the quality of vocational dual expertise teachers. The proposed model framework is developed by analyzing the results of previous scholar studies about teacher achievement and its relationship to teacher. Previous research outlined that there are several factors that can increase the achievements of teachers, which are initial expertise [15-18], teaching experience [17, 19-22], self-efficacy [23-25], and transferable skills [26, 27]. The results of the analysis will be used as base to design and develop a conceptual model framework to improve dual expertise teacher quality in terms of initial expertise, teaching experience, self-efficacy, and transferable skills.

\section{RESULT AND DISCUSSION}

Teacher achievement becomes a reflection of the quality of vocational teachers. In addition to the quantity of teachers is met, the quality of teachers must be fulfilled due to the availability of qualified vocational teachers will be able to encourage the successfulness of educational programs [28]. Qualified teachers will be able to increase the capability of control of the teaching materials, instructional management, and the teaching that will increase student learning performance [28, 29]. If learning outcomes are not met, then teacher is blamed most even though learning is not only influenced by the teacher $[12,18,21]$.

One effort that can be implemented is to improve the quality of existing teachers with the hope of improving instruction teacher in classroom [30]. Teachers who have sufficient knowledge will be better able to adapt to the changing needs of the workforce faced by vocational graduates when his capabilities are enhanced [31]. Improving teachers quality can be through the development of pedagogical and enriching skills which already mastered by the teacher with active involvement of educators directly [32]. This has been pursued by the Indonesian government through the DEP [13]. This is an attempt by the government to meet the quantity of qualified vocational teachers in Indonesia. Apart from this, investigations related to the exploration of factors that influence teacher quality are still needed. Based on the investigation, there are two major factors affect the quality of vocational teachers, including hard skills and soft skills.

\subsection{Hard skill factors}

Hard skill aspects such as teacher competence is one of the determinants of teacher quality [33]. There are several factors driving the increase in the achievements of teachers, among which are initial expertise [15-18] and teaching experience [17, 19-22].

\subsubsection{Teachers initial expertise}

Initial expertise can be described as early teacher proficiency in the expertise package and uses the past experience used to achieve the goals, especially in educational practice [18]. This point is a consideration of factors that influence the quality of vocational teachers, especially for DEP graduates, where vocational teachers are given additional teaching authority from initial skills that are different from the skills chosen during teacher training on DEP [11]. Teacher expertise will be associated with professional capacity, such as knowledge, skills, behaviors, and traits associated with learning teacher student [34]. Expertise of teachers will affect the behavior of teaching [34].

Teachers ability level is reflected in the expertise possessed by the teacher. Initial expertise contributes to effective learning demonstrated by the learners achievement [15-18]. More competent teachers will be easier to achieve, because they can optimize the achievements of them in using school resources to achieve the learning objectives that can ultimately improve student achievement [21]. Teacher expertise will be able to contribute to the achievement of teachers $[35,36]$.

\subsubsection{Teaching experience}

Ideally teacher achievement is good, because it can improve the quality of education, especially the quality of the learners. Teachers chievement is demonstrated to the satisfaction of the students which 
influenced by the teachers' teaching experience and expertise of the teacher [35, 36], beside training, business, cognitive load, and individual differences [37]. Thus, teaching experience can affect teacher performance improvement shown by the students achievements [38, 39].

Teaching experience is one factor that plays a role to improve teachers performance, especially in terms of productivity [19]. Educators must possess the qualifications acquired through professional preparation and experience in the sphere of academic [20]. Teaching experiences and teaching hours will be related to the productivity of teachers and can improve the performance of teachers $[17,21]$. Because of high experienced teachers have a performance that is more effective than less experienced teachers [22]. Experience training and career preparation program teacher influence on the experience of teachers [22]. Experience an effect on improving the quality of teachers' work, evidenced by student achievement [22]. Research result mentioned that the experience of teachers is a major predictor of academic students performance and teachers productivity [21].

\subsection{Soft skills factors}

Soft skills are aspects of the attitudes of vocational teachers that can affect teacher achievement [40]. Previous research outlined that there are several factors that can increase the achievements of teachers, which are self-efficacy [23-25], and transferable skills [26, 27].

\subsubsection{Self-efficacy}

Teaching experience and improvement of knowledge and skills can improve teachers self-efficacy [24, 41, 42]. This is in line with the Vocational Education Revitalization expectations of Vocational Education Revitalization which expects both students and teachers have high levels of selfefficacy so that they have a good capability [14]. Teachers self-efficacy associated with the desired learning objectives to improve learners' learning [23]. Self-efficacy helps teacher to decide what action they should pursue in learning and persist in the face of adversity [24].

Self-efficacy can have an impact on teachers' achievements, such as research which showed that self-efficacy positive effect on the satisfaction of the teachers at the school, so the performance will also increase [23, 43, 44]. Self-efficacy can increase both students and teachers achievement [24]. Teacher with low self-efficacy can reduce the performance of learners [25]. Teachers with low self-efficacy tend to have negative tendencies related to teaching and narrow perspectives related to problem solving [25]. So, the quality is less than optimal.

\subsubsection{Transferable skill}

Blend between initial expertise and professional experience can form a transferable skill [45, 46]. Transferable skills is one of the skills needed to be transferred and adapted to the various needs and different working environments [47]. Transferable skill is one of the important skills possessed by young people and in the future, because potential workforce will be recruited by industry if they have a good transferable skills [47-49].

Today, the schools need teachers who are able to use good communication skills to learners [50]. In addition, teachers with such a good class leadership would be more desirable to teach in schools [51, 52]. The working conditions are ever-changing world demands for vocational teachers to up-to-date with world demand for labor related work of vocational graduates [53]. Therefore, vocational teachers should have such communicative abilities, leadership, and ability to evolve in order to survive in the ever-changing teaching environment. Thus, vocational teachers must be able to have a good transferable skills to succeed in work organization $[26,27,46]$.

\subsection{Conceptual model framework to improve quality of vocational teachers in Indonesia}

The results of the study above shows that: (1) teachers' initial expertise and teaching experience can improve the teachers achievement; (2) teachers' self-efficacy and transferable skills can improve teachers achievement; and (3) teachers' initial expertise and teaching experience can improve teachers' self-efficacy and transferable skills. Based on this, its concluded that the quality of dual expertise vocational teachers can be improved through increasing the variables include the initial expertise, teaching experience, self-efficacy, and transferable skills. The conceptual model framework is shown in Figure 1. 


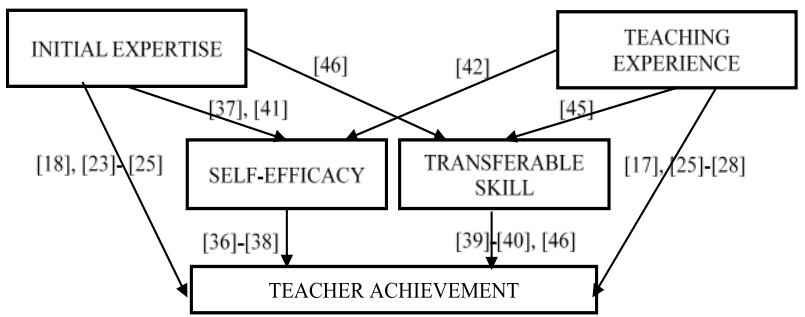

Figure 1. Conceptual model framework

\section{CONCLUSION}

The core of this article is how to improve the quality of vocational teachers, especially the dual expertise vocational teachers. This study uses several theoretical studies related to teachers' initial expertise, teaching experience, self-efficacy, and transferable skills. Two main components that can improve the quality of dual expertise teachers are self-efficacy and transferable skills. Each component is also supported by teachers' initial expertise and teaching experience.

To improve the quality of vocational teachers, especially dual expertise teachers, teacher achievement can be improved through increasing self-efficacy and transferable skills, in addition to pay attention to the teachers' initial expertise and teaching experience. The conceptual model has been established theoretically and empirical results referred to with previous research. Therefore, conceptual models need to be tested.

\section{ACKNOWLEDGEMENTS}

Our sincere thanks are addressed to the Endowment Fund for Education (LPDP) Ministry of Finance Republic of Indonesia (Kemenkeu RI) as a funder of this research project through BUDI-DN scholarship.

\section{REFERENCES}

[1] Y. Estriyanto, S. Kersten, P. Pardjono, and H. Sofyan, "The missing productive vocational high school teacher competency standard in the Indonesian education system," J. Tech. Educ. Train., vol. 9, no. 1, pp. 26-44, 2017.

[2] S. Billet, Vocational Education: Purposes, Traditions, and Prospects. New York: Springer, 2011.

[3] A. P. Sasmito, "Work readiness of software engineering student in Batu City," in International Conference on Vocational Education And Training (ICOVET 2017) Work, vol. 116, pp. 67-70, 2017.

[4] C. C. Calhoun and A. V. Finch, Vocational education: Concepts and operations. California: Wadsworth Publishing Company, 1982.

[5] C. R. Finch and J. R. Crunkilton, Curriculum development in vocational and technical education third edition. Boston: Allyn and Bacon Inc, 1989.

[6] T. A. Sutikno, "Cooperation between vocational high schools (VHS) and industry to increase the number of hired graduates: Multi-case study on three VHSS," Glob. J. Eng. Educ., vol. 16, no. 3, pp. 141-145, 2014.

[7] N. J. Pearse, "Change management in a VUCA World," in Visionary Leadership in a Turbulent World, R. Elkington, M. Van Der Steege, J. Glick-Smith, and J. M. Breen, Eds. 2017, pp. 81-105.

[8] T. C. Reeves and P. M. Reeves, "Educational technology research in a VUCA World," Educ. Technol., vol. 55, no. 2, pp. 26-30, 2015.

[9] B. Cousins, "Design thinking: Organizational learning in VUCA environments," Acad. Strateg. Manag. J., vol. 17, no. 2, pp. 1-18, 2018.

[10] A. Rosser, "Beyond access : Making Indonesia's education system work," 2018.

[11] Kemendikbud, Skills certification program guide and educator certification for vocational school teachers (dual skills) (in Bahasa). 2016.

[12] D. Sulisworo, R. Nasir, and I. Maryani, "Identification of teachers' problems in Indonesia on facing global community," Int. J. Res. Stud. Educ., vol. 6, no. 2, pp. 81-90, 2016.

[13] A. P. Sasmito, D. Kustono, Purnomo, and H. Elmunsyah, "Evaluation Framework for the implementation of the dual expertise program and its results," in 2nd International Conference on Vocational Education and Training (ICOVET 2018), vol. 242, no. Icovet 2018, pp. 136-138, 2019

[14] Kemendikbud, Revitalisasi Pendidikan Vokasi. 2016.

[15] J. König, S. Lammerding, G. Nold, A. Rohde, S. Strauß, and S. Tachtsoglou, "Teachers' Professional knowledge for teaching english as a foreign Language: Assessing the Outcomes of Teacher Education," J. Teach. Educ., vol. 67, no. 4, pp. 320-337, 2016. 
[16] M. M. Keller, K. Neumann, and H. E. Fischer, "The impact of physics teachers' pedagogical content knowledge and motivation on students' achievement and interest," J. Res. Sci. Teach., vol. 54, no. 5, pp. 586-614, 2017.

[17] O. T. Owolabi and J. O. Adedayo, "Effect of teacher's qualification on the performance of senior secondary school physics students: Implication on technology in Nigeria," English Lang. Teach., vol. 5, no. 6, pp. 72-76, 2012.

[18] M. Turu, "Understanding School Teachers' Perceptions of expertise: Impact on Initial teacher education programmes," in Proceedings of the 2016 STORIES Conference, pp. 1-6, 2016.

[19] J. K. Rice, "The Impact of teacher experience examining the evidence and policy implications," CALDER Work. Pap., vol. 11, pp. 1-8, August 2010.

[20] P. S. Turocy, "The impact of instructor expertise and competency on student learning and strategies for improvement," Athl. Train. Educ. J., vol. 10, no. 4, pp. 328-331, 2015.

[21] O. J. Adesina, S. O. Raimi, O. A. Bolaji, and A. E. Adesina, "Teachers attitude, years of teaching experience and self-efficacy as determinants of teachers productivity in teachers professional development programme in Ibadan Metropolis, Oyo State, Nigeria," J. Emerg. Trends Educ. Res. Policy Stud., vol. 7, no. 3, pp. 204-211, 2016.

[22] J. K. Rice, "Learning from experience? Evidence on the impact and distribution of teacher experience and the implications for teacher policy," Educ. Financ. Policy, vol. 8, no. 3, pp. 332-348, 2013.

[23] M. E. Türkoğlu, R. Cansoy, and H. Parlar, "Examining Relationship between teachers' self-efficacy and job satisfaction," Universal Journal of Educational Research, vol. 5, no. 5, pp. 765-772, 2017.

[24] M. Zee and H. M. Y. Koomen, "Teacher self-efficacy and its effects on classroom processes, Student Academic Adjustment, and Teacher Well-Being," Rev. Educ. Res., vol. 86, no. 4, pp. 981-1015, 2016.

[25] S. L. Battersby and A. Cave, "Preservice classroom teachers' preconceived attitudes, confidence, beliefs, and selfefficacy toward integrating music in the elementary curriculum," Updat. Appl. Res. Music Educ., vol. 32, no. 2, pp. 52-59, 2014.

[26] K. Lowden, Intelligenc in the flesh, no. October. London: The SCRE Centre Research in Education University of Glasgow, 2009.

[27] J. Deal and S. A. Hegde, "The development of transferable skills in a variety of economics courses," Int. Res. Educ., vol. 3, no. 2, p. 145, 2015.

[28] A. Hakim, "Contribution of competence teacher (Pedagogical, Personality, professional competence and social) On the Performance of Learning," Int. J. Eng. Sci., vol. 4, no. 2, pp. 1-12, 2015.

[29] A. A. Ferraresi, S. A. Santos, J. R. Frega, and H. J. Pereira, "Knowledge management, market orientation, innovativeness and organizational outcomes: a study in companies installed in Brazil," J. Inf. Syst. Technol. Manag., vol. 9, no. 1, pp. 89-108, 2012.

[30] D. Wiliam, "Teacher expertise: why it matters, and how to get more of it," in Licensed to Create: Ten Essays on Improving Teacher Quality, J. Hallgarten, L. Bamfield, and K. McCarthy, Eds. London: The RSA Action and Research Centre, pp. 27-36, 2014.

[31] C. Ridzwan, S. Malik, Z. Hanapi, S. Mohamed, M. Hussain, and S. Shahrudin, "Skills and knowledge competency of technical and vocational education and training graduate," Asian Soc. Sci., vol. 13, no. 4, p. 69, 2017.

[32] A. M. Hightower, S. C. Lloyd, and C. B. Swanson, Improving student learning by supporting quality teaching, December 2011.

[33] W. H. Ko and Y. H. Chiu, "Developing teaching quality indicators for the culinary teacher in a university,"World Trans. Eng. Technol. Educ., vol. 9, no. 2, pp. 114-118, 2011.

[34] D. Choe, S. Y. Lee, and S. S. Kim, "A study on the effects of teacher creativity and teaching expertise on creative teaching behaviors," Adv. Sci. Technol. Lett., vol. 127, no. 1, pp. 59-64, 2016.

[35] J. O. Fehintola, "Teachers' characteristics as correlates of students' academic performance among secondary school students in saki-west local government area of Oyo State," Journal Education Soc. Res., vol. 4, no. 6, pp. 459-468, 2014.

[36] U. Aslam, "The impact of teacher qualifications and experience on student satisfaction: a mediating and moderating research model," Pakistan J. Commer. Soc. Sci., vol. 10, no. 3, pp. 505-524, 2016.

[37] M. Jipp, "Expertise development with different types of automation: A function of different cognitive abilities," Hum. Factors, vol. 58, no. 1, pp. 92-106, 2016.

[38] T. Kini and A. Podolsky, Does teaching experience increase teacher effectiveness? A Review of the Research, Palo Alto: Learning Policy Institute, 2016.

[39] A. A. Adetona, "Student and teacher factors as predictors of student achievement in federal school of statistics Ibadan," Int. J. Eval. Res. Educ., vol. 6, no. 2, p. 79, 2017.

[40] H. Hendriana, "Teachers' hard and soft skills in innovative teaching of mathematics," World Trans. Eng. Technol. Educ., vol. 15, no. 2, pp. 145-150, 2017.

[41] M. A. Rowbotham, The impact of faculty development on teacher self-efficacy, skills and retention. Edwardsville, Illinois Education Research Council at Southern Illinois University Edwardsville, 2015.

[42] J. H. Yoo, "The effect of professional development on teacher efficacy and teachers' self-analysis of their efficacy change," J. Teach. Educ. Sustain., vol. 18, no. 1, pp. 84-94, 2016.

[43] S. Avsec and A. Szewczyk-Zakrzewska, "Engineering students' self-efficacy and goal orientations in relation to their engineering design ability," Glob. J. Eng. Educ., vol. 20, no. 2, pp. 85-90, 2018. 
[44] Y. B. Doğan, H. Akar, and M. Üstüner, "Examining the measurement invariance of the teachers' sense of selfefficacy scale in terms of gender," Int. J. Eval. Res. Educ., vol. 8, no. 2, pp. 213-220, 2019.

[45] I. Barbosa, C. Freire, and M. P. Santos, "The transferable skills development programme of a Portuguese economics and management faculty: The perceptions of graduate students," Competencies Talent Manag., pp. 25-47, 2017.

[46] M. A. Matsura, O. A. Imam, and S. Osman, "Employability skills and task performance of employees in government sector," Int. J. Humanit. Soc. Sci., vol. 3, no. 4, pp. 150-162, 2013.

[47] UNESCO, Transversal Skills in TVET : Policy Implications. 2015.

[48] Marsono, Purnomo, Tuwoso, M. Romlie, and Solichin, "The urgency of transferable skills development for vocational teacher: A literature review study in Indonesia," in 1st International Conference on Technology and Vocational Teachers (ICTVT 2017), 2017.

[49] N. Qomariyah, T. Savitri, T. Hadianto, and M. Claramita, "Formulating employability skills for graduates of public health study program," Int. J. Eval. Res. Educ., vol. 5, no. 1, p. 22, 2016.

[50] A. Paolini, "Enhancing teaching effectiveness and student learning outcomes," J. Eff. Teach., vol. 15, no. 1, pp. 20-33, 2015.

[51] H. Lowery-moore, R. M. Latimer, and V. M. Villate, "The essence of teacher leadership: a phenomenological inquiry of professional growth," Int. J. Teach. Leadersh., vol. 7, no. 1, pp. 1-16, 2016.

[52] R. Lee-piggott, "When teachers lead: An analysis of teacher leadership in one primary school," Caribb. Curric., vol. 22, no. 1, pp. 105-132, 2014

[53] A. Fejes and S. Köpsén, "Vocational teachers' identity formation through boundary crossing," J. Educ. Work, vol. 27, no. 3, pp. 265-283, 2014.

Int. J. Eval. \& Res. Educ. Vol. 9, No. 1, March 2020: 39 - 44 